\title{
ROSA CHACEL'S PORTRAYING THE ARTIST AFTER JOYCE'S A PORTRAIT OF THE ARTIST
}

\author{
Luisa-Fernanda RODRÍGUEZ \\ Universidad de León
}

It is a surprise for the contemporary reader to come across a woman writer who recognizes James Joyce as the only clear influece she had when she decided to become a novelist. (Triunfo 473 June 1971, 60-61): She said in 1988 in a special number dedicated to her "Sali para Roma... Este fue el punto de partida de mi vida profesional, allí escribi mi primera novela Estación. Ida y vuelta impulsada por el conocimiento de Joyce... Al salir de España conocí el Retrato recién traducido por Dámaso Alonso y dije en mi fuero interno: esto es la novela» («Autopercepción Intelectual. Autobiografía Intelectual», Anthropos 85: 1988, 26") ${ }^{3}$. In the preface to Estación. Ida y vuella (1930) we read. "Este libro publicado en Madrid por la editorial Ulises en 1930. fue escrilo en Roma en el invierno del 25 al $26 . .$. Puedo todavía señalar dos cosas culminantes que aparecieron poco después del 20: la traducción del primer tomo de Freud.... y la traducción del «El retrato del artista adolescente». El descubrimiento de Joyce me dio la seguridad de que, en novela, todo se puede hacer: poesia, belleza, pertinacia de la fe...Con este equipaje me fui a Roma, reciencasada, en 1922. (18)

In her published diaries the reference to Joyce's incluence is recognized several times ${ }^{3}$. Rosa Chacel was born in Valladolid in 1898 (June. 2), the same year as Dámaso Alonso, Federico García Lorca and Vicente Alexandre. Her life is similar to the lives of the majority of the writers and artists that lived in exile during or inmediately after the Civil War. She left Europe for Southern America, Brazil, in 1940 and moved to Buenos Aires in 1942

1 «l left for Rome.. that was the starting point of my professional life. There 1 wrote my lirst novel Estación. Ida y vuelta under the impulse of James Joyec. When! left Spain I knew the Portrait ...just translated by Dámaso Alonso and I said to myself, this is the novely (The translations of the fragments of Rosa Chacel are mine).

2 «This book published in Madrid by the editorial Ulyses in 1930, was written in Home in the winter of $1925-1926$... I can still point to two things of paramount importance in the twenties: the translation of the first volume of Freud...and the translation of aRetrato del artista adolescenter. My discovery of Joyce gave me the certainty that in the novel, anything could be done: poetry, beauty, thought, ugliness, blasphemy... With this luggage 1 left lor Rome, just married, in 1922".

I There are several references to Joyce"s Dedalus (Alcancia. Ida. Alcancía. Vuelta 1982. Vol. 2, 183-84, 187) and to Ulysses in purticular aEl Ulises me abruma, pero no como lectura. Me abruma porque me hace ver lo imposible de mis pretensionesn "Ulysses overwhelms me. But not as a reading, but because it makes me see the impossiblity of my ambitionsw (vol. 2,185 ) She also wrote an entry on the 20th of March. 1969 that she had read Ulysses when she published Estacion. Ida y vuelta. 
where she published in Sur, The Nation and other prestigious periodicals, She visited Spain for the first time after her exile in the 1960 and she came back to stay in 1973. A grant by the Juan March Foundation allowed her to write Barrio de Maravillas (1976), an old project. Memorias de Leticia Valle which she had started in Paris was published in 1945, the lirst chapter having appeared in Sur in 1939, the year of Finnegans Wake. She always mantained that the roots of everything essential to her life were there, in her childhood. However, when she was ten years old the family moved to Madrid, where she was educated at home, until she attended the School of Arts of San Fernando and this is the subject matter of Barrio de Maravillas the book in which I intend to centre my attention.

The day the International Symposium on James Joyce finished in Seville (June 18, 1994) she was taken to Hospital seriously ill. She died a few weeks later at the age of 96 , having remained lucid almost to the very last moment. She published more than 30 titles which include liction, poetry and essays. She always complained about the fact that her work was not understood in Spain. The truth is that perhaps her novels of growth were published and perhaps written at the wrong moment. A good deal of her writing has to do with autobiography, which has not been a popular literary convention in Spain until very recently.

She belongs to the so-called generation of 27 (also known as the generation of the Dictatorship) not only because of the date of her birth but because she lived under the same literary influences. However, the poets like García Lorca, Dámaso Alonso. Vicente Aleixandre. Jorge Guillen, Luis Cernuda, etc. were by far the more popular, writers of fiction were almost unknown. When she joined the company of Ortega y Gasset she was not a convinced student of art in the Arts School. She intended to be a sculptress, but in 1918-1920 she established contacts with Ortega y Gasset, the Spanish avantgarde, Ultraism, and later in 1924-1926 in Paris, she was very much impressed by Surrealism and also by the Poe translated by Baudelaire. She came back to Spain in 1927 from a short exile that had been also from the artistic point of view a journey of initiation, her first one of separation and return.

As has been said already, James Joyce's work was known in the Spain of the 1920s (Crespo y Rodriguez «A Portrait of the Artist as a Young Man, su traducción y Rosa Chacel» Sevilla, 1982). The vehicle was Revista de Occidente which is the same as to say Ortega y Gasset, where in 1924 Antonio Marichalar wrote «James Joyce en su laberinto» («James Joyce in his Labyrinth» which later became the preface to Damaso Alonso's translation of the Portrait). The other source in Spanish language was Jorge Luis Borges. Rosa Chacel has said that she was already familiar with Joyce's work in 1922, but Dámaso Alonso wrote to us that it was not until 1924 that he first made contact with Joyce's work. He translated it the year he was in Cambridge (Letter written to us in January 1982). It was very much celebrated in number 13 of Revista de Occidente (September 1926, 383) by 
one of the prose writers of that generation. Benjamin Jarnés. All the information about the vicissitudes of this translation was published by Alan M. Cohn in 1963 who was himself in contact with Dámaso Alonso4. This means that Rosa Chacel had not seen the Spanish translation in 1922 as it did not exist, neither the French one that appeared in 1924, and she did not know English at the time. (She started to learn it in 1950 [Alcancia.Ida, 172]. Probably her memory fuiled when in 1974 she wrote the "Noticia" that was added as a prologue to the second edition of Estación.Ida y uuelta (Madrid, 1980).

But as she was a regular visitor to the very exclusive literary gatherings of Ortega y Gasset in the office in which Revista de Occidente was edited she might have heard of the Portrait there. Ortega, the disciple of Kant, had been eductated by the Jesuits, had renounced his faith, and his education that was completed in Germany, was also both his house and prison. Francisco Ayala says in his memoirs (Recuerdos y Olvidos 1988,107 ) that Rosa Chacel was one of the «intellectual» ladies that attended regularly those literary gatherings. I said in 1982 that Joyce's Portrait had impressed her very much and I offered then a few examples that showed Joyce's influence, I am not going to repeat here what is already there.

What interests me most now is the way she assimilated, digested, transformed and introduced innovations in Joyce's impulse. How she conceived the growth of the artist as a young woman in rhetorical terms, in terms of her self awareness; the classical awakening of the soul and the awareness of the body, awareness of the place, of her sex and the time she lived in. That is why I am going to focus this paper on her most explicit novel of the growth of the artist as a young woman Barrio de Maravillas (1980). The book was already in Rosa Chacel's mind long before. It was started when she was in Rome, it underwent changes, in 1955 she already had the two central characters and was doubting about the tille, as «Maravillas» was not such a well known quarter as Pigalle as she says in her diary Alcancia.Ida. $(46,182,220)$; on the 20th of December 1965 we come across this entry aMe leí por enésima vez el Dedalus, de Joyce, y me sentí en la fuente. Ningún libro tuvo en mi una influencia más decisiva ni mäs duradera" (ibid. 437$)^{5}$ and later she wrote "l must start right now B. de M.». The old project was written when she was back in Spain, her fourth separation and her fourth return. It is the first of a trilogy, the other two titles being Acrópolis (1984) and Ciencias Naturales (1988).

4 Revue de Liltérature Comparée, 37 (1963),405-409; Dåmaso Alonso himself sent it to us together with the letter I mention.

5 \&I read once more the Dedalus by Joyce, and I felt mysell at the source. Never before had a book an influence more decisive and more lasting*. 
II

A definition of Künstellroman is that it is a genre that glorifies the struggle of youth preoccuped with becoming a Creator in spite of everything and at any cost. Stephen Dedalus could be reduced to this. The artist who renounces everything, family, religion or nationality before renouncing what he considers his destiny has attracted social applause. In one of those titles the Academic Industry produces regularly we come across this statement which I find to the point: the wish to write a Bildungsroman or a Künstlerroman is no more than a display of egoism, «selfishness underlaying all». This means that the Narcissus that is rellected in the mirror of fiction is despicable. As for the woman artist: "Satan ...is too glad to instruct still another insatiable Eve in the knowledge of good and evil» (A Portrait of the Artist as a Young Woman 1985. 1). The problem was in the past that women began to occupy a different status in the world of art, they became the subject of creation and not the object, they passed from Muses to Artists. It has been stated that in the Anglosaxon speaking world the novel of artist written by women or feminine Künstelrroman is a late production considering masculine Künstlerroman. It has been demonstrated that it is difficult to remember a serious work of art that celebrates «her struggle to become an artist. Where is the heroine who has the ambition of Stephen Dedalus... Where is the female equivalent of $A$ Portrait of The Artist as a Young Man?" (The Female Imagination 1975: 157).

Maurice Beebe in his Ivory Towers and Sacred Founts (the result of the analysis of more than two hundred titles) descries conventions of the artist's autobiographical portrait and says that the hero (the Hero with Creative Genius) is always the same man: sensible, dreamy, passive, tormented, egocentric, misunderstood and of course very learned; he always shows an internal conllict, inevitably a tension between his sensuality and his spirituality, between the body and the soul, he presents «a divided self»; some of these characteristics had been taken as feminine such as the extreme sensibility. passivity or shyness. This could be the archetypal portrait and corresponds to the identity of Stephen Dedalus.

Spain is a country whose autobiographical production has been rare. Only a few specimens appeared at the beginning of the century. The reasons could be found in the fact that autobiographical writing has been outside our literary tradition: confessions, memoirs and autobiography do not belong to Spanish idiosyncrasy for reasons I am not prepared to give here; even biography has been scarce. Only in the last twenty years has there been a greater display of autobiographical writing but Künstlerroman has been almost a forbidden product in our literary garden; autobiographical novels that portray the heroes' efforts to become artists and participate in this way in their share of divinity were almost nonexistent. If male writing of this kind has been a rare genre, portraits of female artists did not exist in the first 25 years of this century. In any case one can singularize Juan Ramón Jiménez' Diario de un poeta reciencasado (1918), Manuel Azaña's El Jardin de los Frailes first in serial form (La Pluma September 1921-June 1922), later edited in book form 
in 1926. It gathers autobiographical material and tells the story of the growth of a young man and the growth of his mind while he was studing with the order of St. Agustin. María Teresa León's work Memorias de la Melancolia (1925) is also especially remarkable.

Still, in the second half of the twentieth century the woman artist as the heroine of fiction was missing. Here, like in many other countries one of the common questions in Women's Studies concerning literary matters is the same, "where is the heroine with the ambition of Stephen Dedalus?». In the case of Rosa Chacel's novel Barrio de Maravillas we have two heroines, Isabel and Elena. The former being at the center and the matter of her art still to be discovered. Unlike Stephen Dedalus who dismissed the companionship of the character modelled on his brother Stanislaus (in the first rejected version of Portrait) lsabel is not alone in her apprenticeship. She is always guided by Elena the daughter of Ariadna. It is in Ariadna's house that the narrative starts, when our heroine is haunted by at word she doesn't know, while sitting by the window doing some embroidery.

Ariadna's role in this book is central. As Dedalus was the craftsman, the builder of the labyrinth, she initiated heroes. She helped Theseus who came to slay the Minotaur in the labyrinth. She gave him the clue of the thread to guide him; she also saved Dedalus. She is abandoned by Theseus in the island of Naxos where she was discovered by Dionysius, who married her and she was honoured as a goddess. This is a famous story repeated in art. As a deserted woman abandoned by her lover she has been the prototype of the sulfering woman and, as a matter of course, a symbol for the feminists. She is doubtless a complement to the literary rebirth of the myth of the Jabyrinth (Juan Ramon Jiménez's Laberinto 1911, was a precedent in Spanish literature), her thread is sheer reason. It is a myth assimilated to time and to identity. Ariadna is redeemed and made a goddess, she is between two destinies. Out of this confrontation doubt is still there, engaged either with love or with the development of her own possibilities. Rosa Chacel also builds her own labyrinth: to think means to enter the labyrinth and risk getting lost. Like Stephen Dedalus who avoided being trapped by the nets of home, country and religion she builds a labyrinth of words which she will master, and of which she will have the key. And this is not talking nonsense for Ariadna is omnipresent in the novel, and wherever she appears she is the light-bringer: Ariadna illuminates with her light wherever she goes, in a humble house «The shoemaker thinks the light grows when Ariadna comes down" («el zapatero cree ver crecer la luz cuando baja Ariadna», 55). "Ariadna claims all she was to become» («Ariadna reclama todo to que fue, para poder ser», 56). Ariadna takes for certain that she wants to find the exceptional, the singular, and the unique, which is the destiny of the chosen. And she is described in terms of a personality fragmented, in between two destinies, "El furor de una ménade no seria para el dios más que la voz del coro. Lo unico, lo singular, lo personal en fin tenia que ser una nota cuya excelencia, cuya esencia sublime sumiese al dios en un éxtasis... habia que encontrar la nota justa. la nota que conmueve a las piedras... la nota que 
hace sallar toda la ley arquitectónica (56-57)... el maestro bendijo la unión del poeta con Ariadna...Alli mismo donde había nacido. Ariadna ponia en el mundo una mujercila ... las dos, madre e hija habia sido poseidas en su desnudez, en su futurible virginidad por la luz de junio... decidieron ponerle el nombre irreprochable de Elena (66-70)".

In this book Ariadna is the patron saint, not only as the chosen woman, but also as companion to the girls, under whose protection they are capable of learning: Ariadna identilied with the girls created or shared with them all those «secret hours" (256).

In this book the awareness of the spirit comes in the form of awareness of language. It is not as in Portrail where the language grows, but in successive epiphanies. It is Elena, Ariadna's daughter, that unveils for Isabel the mysteries of words. This is the very beginning of the book, Isabel pulling out the threads of a piece of old linen. It is a word she hears, a word referring to her, which is the thread that departs from the family room where women visitors gather and from the image of Isabel sewing by the window, where the light of the sun illuminates her profile and enhances her blond hair like an old painting. It is here that she hears the mysterious word referring to her: "...Parece tan bien educada...y tan rubia como una princesita". " ¿Como una princesita...? -voz hombruna, terminante-. Lo que parece, de cabo a rabo...» $(1980: 14)^{\top}$. The word is not formulated and the reader is also ignorant. The narrator uses Isabel's thought as focus and in her thought, darkness: Oscuridad, oscuridad, que estalla como una bomba. Una bomba que, en vez de producir una llamarada produce sombra, apaga todas las luces, la del pensamiento, la del sentido común. Una palabra que es una bomba de vacio. Es lo incomprensible. lo irrespirable, hostil a la vida. Y la palabra se repite y cuando más se repite más oscura parece, más malvada, más sarcástica, más infamante... El uiltimo hilo sale como si saliese de la inmundicia, como sifuera viscoso; no acaba de salir nunca, se rompe, hay que buscarlo...(14)

The unveiling of the mystery is presented in terms of revelation, and the

65 «The furore of the maenad could not be more than the voice of the chorus for the god. The unique, the singular, the personal had to be a note whose excellence. whose sublime essence would lead the god to eestasy...It was necessary to discover the right note. the note that moves the stones...the note that bursis all the architectonic laws... The master blessed the union of the poet with Ariadna... in the same place where she was born, Ariadna gave birth to a little girl...the two, the mother and the daughter have been possessed in their nakedness, in their future virginity, by the light of June... They decided to give her the spotless name of [i]enam.

${ }^{7}$ «She looks so well educated... and so blonde like a little princess. -Like a little princess...? - masculine, unhesitant voice- what she looks like from top to bottom ...

"Darkness, darkness that burst like a bomb. A bomb that does not produce fame, it produces a shadow, it puts out all the lights: the lights of thought, of common sense...And the word repeats itsel $\Gamma$ and the more it is repeated the darker it appears, more devilish, more sarcastic, more infamous... The last thread comes as if out of the dirt, as if it were viscous..." 
whole process is treated in religious terms. Isabel expresses her fears and formulates the question to Elena who starts the preparations for discovery (it takes more than fifteen pages, from 14 to 31) which is expressed in terms of the ritual ceremony of initiation: after a sleepless night Isabel dressed in the fushion of a 17 th century portrait, her long blonde hair washed, she is taken not to church but to the Prado Museum on a Sunday morning. Elena says to her «Un museo es un templo, para mi» ("to me, a museum is a temple») (35). Elena's father accompanies them. And this is how Isabel passes from the obscurity of innocence to the light of knowledge of that particular word. The word is "carreño", "she looks like a carreño», later capitalized and transformed into Carreño, the 17 th century painter Juan Carreño de Miranda, once they are in front of his paintings in the Museum. The reaction of the girl is described as follows, ¿Qués es lo que pasa cuando uno pasa...? (in front of the paintings) ¿Qué es lo que ve? En el primer momento no ve nada... y eso que no ve es como una visión como para olvidar todo lo que ha visto antes... Es como si de pronto tuviera uno delante lo que no puede ser... Uno está viendo. está oliendo un aire que no ha olido nunca. está oyendo un silencio, como una quietud, una luz...(31)".

Elena wants her to see, the father following close, «Los Carreños" at the end of the room(32). In terms of epiphany Isabel is lirst «seeing», with the eyes of the body and with the eyes of the spirit. Her physical description is also of interest: Like Stephen Dedalus Isabel is not strong. she is pale and thin (32). and looks like the characters in Carreño's portraits because they were «anaemic». She follows the stereotype of the delicate girl, however her character is strong, and her stubborness is more than remarkable in her determination to learn.

Rosa Chacel's novel presents men playing different roles. They can be messangers from the world outside the house or outside the feminine environment. It is the father, his or Elena's, that brings home the news of culture and provides with the means of learning, music, the pencils and the oils, new books, sometimes a rarity he finds in a second-hand book shop, the book is not always complete, some pages missing or badly kept «Mi padre dobla la esquina cargado con un paquete enorme. Me había asegurado que la traería a cualquier precio» (191) ${ }^{10}$. The parcel that seems enormous to the girl's eyes contains inside, carefully wrapped, an old copy of the Divine Comedy. In other feminine novels of initiation men are presented as demanding time and altention. Here they are present as helpers as is the case of the father.

They play another role, they are used as means of constrasting the growth

" "What happens when one passes by...? Nothing... What is it that one sees?... Nothing, in the first moment... and that which one does not see is a vision like lorgetting what it has seen before...It is as if suddenly one has before one what cannot be... One is seeing, smelling an air that has not been smelled before, one is listening to a silence as a stillness, a light, a glitter...m.

to aMy father comes round the corner with an enormous parcel. He told me he would bring it at any costs. 
both of the mind and of the flesh. This is the case with Luis, the son of the chemist who feels attracted by Isabel and causes her embarrassment. His role in the story is to provide the growing mind with the traditional struggle of the fleslt and the spirit which passes through her mind as something that Isabel is not totally able to understand. The awareness of her own body is slow, the growth is seen in terms of changes in clothes (the changes in an adolescent girl were marked in the past by the use of stockings instead of socks). She repeats once and again that she is not going to marry. She is very firm in her purpose of achieving necessary independence.

In A Portrait the vision that inspires the artist is [eminine, the gir] on the beach in an attitude that suggess to Stephen Dedalus the attitude of a bird, symbolic of the freedom of the artist that aspires to fly closer and closer to the light of the sun, in his attempt to reach the divinity (Henry Malraux said that Joyce died of electrocution). It is an idealized model symbolic of the flight that is going to start. It is a passive leminine symbol. The heroine of Barrio de Maravillas never leaves the house where she lives in the quarter of Maravillas in Madrid, today known as Malasaña. She does not leave the house but she is conscious of the fact that «lt is in the summit where confusion lives, it is there where things melt in the happiness of having reached the summit» (136). Her selfconsciousness is the most important issue, her preoccupation with learning and her awareness of the linguistic barriers that separate her from the adult world and from the men's world. She realizes that she has to be born again, for the artistic tradition of words is masculine, as one of her male coleagues of the School of Arts remarks: "You don't understand because you are afraid of words: you don't know how to play with them" (275). The same boy would ask the most important question of all: «Sometimes we talk about you, the women aestheticians... What will be their role?..." (277)"11, and this is perhaps the most important role played by the males in her this novel, to pose the question in this book.

The end of this narrative is meaningful enough. Silence is one of the characteristics of Rosa Chacel's novels expressed in terms of unfinished sentences and question marks. The unsolved problems will remain in the rest of her literary production, questioning is omnipresent. The end of the book takes place in the Madrid of the First World War. In the final paragraph the two girls return home, in silence: No llegaron a saberlo, por más que pensaron mientras fue cayendo la tarde. Pasaron mucho tiempo en silencio, pero no bastante tiempo, no bastantes años, no los suficientes para saber algo. Cuando ya no se veía más que la estatua con su actitud violenta, con su mano en alto, como el que quiere arrancarse los pelos, se volvieron a casa. ${ }^{12}$

" "-No entendéis porque os da miedo jugar con las palabras: no sabéis jugar con ellas. No sabéis jugar con las cosas serias» (275) «-....A veces hablamos de vosotras...para qué serviran las Es-tetitas?». The word game, that plays with "tetas" Spanish for abust is untranslatable.

12 «They never knew, however they thaught as the day was swooning. They 
One of the important issues of this novel is this linal fragment. It shows how the pattern of the narrative is conceived in a way familiar to the modern novel of growth: every new beginning demanding a new return. It is present in the very titles of several books by Rosa Chacel, this is the meaning of ida y vuelta.

\section{BIBLIOGRAPHICAL REFERENCES}

ANTHROPOS 85, 1988. It includes all information necessary about her own production and critical bibliography.

AYALA, F. Recuerdos y Olvidos Madrid: Alianza Editorial 1988.

BEEBE, Mauricc, Ivory Towers and Sacred Fotnts: The Artist as Hero in Ficlion from Goethe to Joyce NY: New York University Press, 1964.

BERTRAND, J.P, ed. Dictionnaire des mythes littéraires. Editionns du Rocher, 1988.

CRESPO ALLUtE, M.J. Y RODRIGUEZ PALOMERO, L.F Actas/Proceedings

Simposio Internaciontal en el centenario de James Joyce.Sevilla: Universidad de Sevilla 1982. pp. 67-85.

CHACEL, Rosa Estacion.Ida y vuelta, Madrid: Ulises 1930.

- Memorias de Leticia Valle, Buenos Aires: Emecé 1945, just translated into English by Carol Maier; Memoirs of Leticia Valle. Lincoln and London: University of Nebraska Press, 1994).

- Alcancia. Ida-Alcancia. Vuella. Barcelona: Seix Barral, 1982.

- Barrio de Maravillas, Barcelona: Seix Barral, 1976.

- Acrópolis, Barcelona: Scix Barral, 1984.

- Ciencias Naturales, Barcelona: Seix Barral, 1988.

- "Autobiogralía intelectual» Rosa Chacel. Memoria, narrativa y poética de las presencias. ANTHROPOS Suplementos 8, 1988.

- Her Complete works (Obra Completa) have been just edited in Valladolid: Diputación Provincial, Centro de Estudios Literarios «Fundación Jorge Guillen», 1993.

At present Claude Couffon is working in the translation into French of a major novel, La Sinrazón.

GARCIA TORTOSA,F. DE TORO,R. Eds. James Joyce en España.Universidad de La Coruña, Servicio de Publicaciones. 1994.

GILBERT, S. M. GUBAR, S. No Man's Land (Vol I. War of the Words). New Haven and London: Yale University Press, 1987.

IIUFF, L. A Portrait of the Artist as a Young Woman NY: Frederick Ungar Publishing Co. 1985

MEYER SPACKS, P.A. The Female Imagination, NY: Alfred A. Knopf, 1975

remained silent for a long time, but not enough, not years enough, not enough to know anything. When there was nothing else to see but the statue in a violent attitude, with its hend risen as if it were to pluck its hair, they returned home». 